\title{
Shear strengthening of reinforced concrete beams using carbon fiber reinforced polymer laminate: A review
}

\section{Marwan Bllkasem Salah Alferiani ${ }^{1,}$ ". Abdul Aziz Bin Abdul Samad ${ }^{1}$, Blkasem Salah Elrawaff ${ }^{2}$, Noridah Binti Mohamad ${ }^{1}$, Mohd Hilton Bin Ahmad ${ }^{1}$}

${ }^{1}$ Faculty of Civil and Environmental Engineering, UTHM, Malaysia

${ }^{2}$ Department Civil Engineering, Omar Mukhtar University, Libya

\section{Email address:}

mr84bl@yahoo.yhoo.com (M. B. S Alferjani), azizs@uthm.edu.my (A. A. Abdul Samad), mr84bl@hotmail.com (Blkasem S. Elrawaff), noridah@uthm.edu.my (N. Mohamad), hilton@uthm.edu.my (M. Hilton)

\section{To cite this article:}

Marwan Bllkasem Salah Alferjani, Abdul Aziz Bin Abdul Samad, Blkasem Salah Elrawaff, Noridah Binti Mohamad, Mohd Hilton Bin Ahmad. Shear Strengthening of Reinforced Concrete Beams Using Carbon Fiber Reinforced Polymer Laminate: A Review. American Journal of Civil Engineering. Vol. 2, No. 1, 2014, pp. 1-7. doi: 10.11648/j.ajce.20140201.11

\begin{abstract}
Several researches have been carried out on reinforced concrete beams strengthened with fiber reinforced polymer composite. Some of the works focused on shear strengthening compared with flexural strengthening that had the largest share. This paper reviews 10 articles on carbon fiber reinforced polymer strengthened reinforced concrete beams. Finally, this paper attempts to address an important practical issue that is encountered in shear strengthening of beams with carbon fibre reinforced polymer laminate. This paper also proposes a simple method of applying fibre reinforced polymer for strengthening the beam with carbon fibre reinforced polymer.
\end{abstract}

Keywords: Concrete Beams, Carbon Fibre Reinforced Polymer, Shear Strengthening, Flexural Strengthening

\section{Introduction}

The use of fiber reinforced polymer (FRP) materials in civil infrastructure for the repair and strengthening of reinforced concrete structures and also for new constructions has become common practice. The most efficient technique for improving the shear strength of deteriorated $\mathrm{RC}$ members is to externally bond fiber-reinforced polymer (FRP) plates or sheets [1]. FRP composite materials have experienced a continuous increase of use in structural strengthening and repair applications around the world, in the last decade, [2]. In addition, when the FRP was compared with steel materials, it was found that it provided unique opportunities to develop the shapes and forms to facilitate their use in construction. Although, the materials used in FRP for example, fiber and resins are relatively expensive when compared with traditional materials, noting that the crises of equipment for the installation of FRP systems are lower in cost [3]. A review of research studies on shear strengthening, however, revealed that experimental investigations are still needed $[4,5]$.

The use of carbon fiber-reinforced polymers (CFRP) can now be considered common practice in the field of strengthening and rehabilitation of reinforced concrete structures. The effectiveness of this technique is widely documented by theoretical and experimental researches and by applications on real structures. As a consequence, the need of codes is necessary for the development of guidelines in different countries [6]. The CFRP strengthening provides additional flexural or shear reinforcement, the reliability for this material application depends on how well they are bonded and can transfer stress from the concrete component to CFRP laminate [7]. Also, CFRP has made this technique even more acceptable worldwide. Commercially available FRP reinforcing materials are made of continuous aramid (AFRP), carbon (CFRP), and glass (GFRP) fibers.

Possible failure modes of FRP strengthened beams are classified into two types; the first type of failure includes the common failure modes such as; concrete crushing and FRP rupture based on complete composite action, the second type of failure is a premature failure that does not reach full composite action at failure. This type of failure includes: end cover separation, end interfacial delamination, flexural crack induced debonding and shear crack induced debonding. Different failure mechanisms in experimental tests were reported by [8-10]. A more in depth explanation 
of these failure modes can be found in $[11,12]$. Although CFRP composites are known to perform better under environmental action than glass fibre reinforced polymer laminates, no significant differences were detected, seemingly because they failed to rupture of the fibres [13]. In addition, several studies were conducted to identify methods of preventing premature failure with the aim of improving the load capacity and ductility of RC beams. Researchers studied the use of end anchorage techniques, such as; U-straps, L-shape jackets, and steel clamps for preventing premature failure of RC beams strengthened with CFRP [8, 14-23].

\section{Applications of FRP}

There are three broad divisions into which applications of FRP in civil engineering can be classified: applications for new constructions, repairs and rehabilitation applications, and architectural applications. FRPs have widely been used by civil engineers in the design of new construction. Structures such as; bridges and columns built completely out of FRP composites, have demonstrated exceptional durability and effective resistance to the effects of environmental exposure. Retrofitting with adhesive bonded FRP, has been established around the world as an effective method applicable to many types of concrete structural elements such as; columns, beams, slabs and walls. It was there that the first on-site repair by externally bonded FRP took place, in 1991. Since then, strengthening by externally bonded FRP composites has been studied worldwide. This sudden increase in the use of FRP composites was attained after the 1995 Hyogoken Nanbu Earthquake in Japan. By 1997, more than 1,500 concrete structures worldwide had been reinforced with externally bonded FRP composites. "Fig. 1", shows the application of CFRP on site. The other application, use of FRP bars instead of steel reinforcing bars or pre-stressing strands in concrete structures

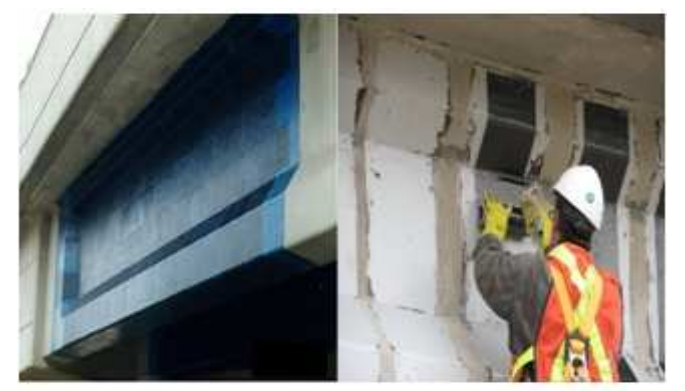

(a)

(b)

Figure 1. Shear strengthening of Reinforced concrete using CFRP laminate

\section{Previous Research Works on Beams}

Investigation on the behaviour of CFRP retrofitted reinforced concrete structures has in the last decade become a very important research field. In terms of experimental application several studies were performed to study the behaviour of retrofitted beams and analyzed the various parameters influencing their behaviour.

Khalifa et al (1999), carried out the test of three simple supports RC T-beams to study the effectiveness of anchorage of surface mounted FRP reinforcement. The first beam was a reference beam, the second beam strengthened with CFRP without end of anchor and the last beam strengthened with CFRP with end of anchor. The anchor system, called U-anchor used GFRP bar inserted in the groove in the beam flange used as end anchor. They found that the shear capacity increased when strengthened with CFRP but, failure was governed by debonding of CFRP when CFRP was used without end anchor. However, the specimen where the anchor was used, shear capacity of the member rather increased and, ultimately no FRP debonding was observed.

Adhikary et al (2004), carried out the tests of eight simple supported RC beams strengthened for shear with CFRP sheet using two different wrapping schemas; U-wrap and two sides of the beam. He investigated the effectiveness of cross plies one over another, vertical and horizontal; the main parameter, direction of fiber alignment $\left(90^{\circ}, 0^{\circ}\right.$ and $90^{\circ}+0^{\circ}$ ) and number of layers ( 1 and 2 ). They observed that the maximum shear strength obtained for the beam with full U-wrapped sheets having vertically aligned fibers. Horizontally aligned fibers also showed enhanced shear strengths as compared to beam with no CFRP. On the other part, they found that the lowest concrete strain was the same load range among all beams. The beam with full U-wrapping of a single layer of CFRP with vertically aligned fibers, was observed at a maximum of $119 \%$ increase in shear strength. Also, they compared with the experimental value, using models for the prediction of shear contribution of sheet to shear capacity of CFRP bonded beams.

Al-Amery (2006) tested six RC beams; having various combinations of CFRP sheet and straps in addition to an un-strengthened beam, as control test. CFRP provided (CFRP sheet for flexural strengthening and CFRP straps for shear strengthening or with a couple of CFRP sheets and straps, for overall strengthening. From the experiment, two beams were tested in four-point bending over a total span of $2300 \mathrm{~mm}$ and a shear span of $700 \mathrm{~mm}$, while the rest RR3-RR6 were tested in three points bending over a total span of $2400 \mathrm{~mm}$ and shear span of $1200 \mathrm{~mm}$. The CFRP sheets consisted of three layers, while CFRP straps consisted of one layer and extra anchorage mechanism for the CFRP sheets. They observed that the use of CFRP straps significantly reduced the interface slip between the CFRP sheets and the concrete section. CFRP straps used to anchor the CFRP sheets, increased in flexural strength of up to $95 \%$. However, with the use of CFRP sheets alone, only an increase of $15 \%$ was achieved. Test results and observations showed that a significant improvement in the beam strength was gained due to the coupling of CFRP straps and sheets. Furthermore, a more ductile behaviour was obtained as the debonding failure was prevented. 
Anil (2006) improved the shear capacity of RC T-beams using unidirectional CFRP composites and compared between the experimental and analytical used ACI Committee report. He tested six beams of sizes; $120 \mathrm{~mm}$ width $360 \mathrm{~mm}$ depth $1750 \mathrm{~mm}$ length and $75 \mathrm{~mm}$ flange thickness. Of these, two beams were control specimen and four beams were strengthened with different configurations of CFRP strips, all these beams were tested under cyclic loading. These beams had longitudinal reinforcement and no stirrups for beams except one of the control beam. The parameters of this case were; 1) CFRP orientation of CFRP $45^{\circ}-135^{\circ}$ and $90^{\circ}, 2$ ) spacing of CFRP was 285 and $143 \mathrm{~mm}, 3)$ CFRP strengthened scheme was both sides and U-wrap, 4) different compressing strengths were used and 5) anchorage was used as steel plates on both sides and (L-shaped). From the results, he observed that the stiffness of the beams were very close. He also observed that the strength and stiffness of the specimens improved by using CFRP unidirectional. On the other side, the analytical shear load capacity showed $20 \%$ less than the experimental shear load capacity, due to using the successful performance of anchorage.

Bencardino et al (2007), presented an experimental and analytical investigation on the shear strengthening of reinforced concrete rectangular beams wrapped with carbon fiber reinforced polymers (CFRP) laminates. A total of four beams were specifically designed, with and without an external anchorage system. The cross sections of $140 \mathrm{~mm} x$ $300 \mathrm{~mm}$ with total length of $5000 \mathrm{~mm}$ were used. The specimens were two control beams with different av/d, one beam with only CFRP and one beam with CFRP + external links. All beams had identical internal reinforcement and were tested under four point bending over an effective span of $4800 \mathrm{~mm}$ and nothing in the shear span but, had stirrups in the near of support. The principle variables included external anchorages, with consisted of six specimens, were classified into two categories; namely BT and BS, each category had eight different lengths in the mode of U-shaped steel stirrup. The results showed that the anchorage system enhances the strength and deformability properties of the CFRP plated beam. Also, the anchorage system modifies the failure mode of the strengthened RC beam under predominant shear force, without increasing the load capacity, to a more ductile failure with a substantial increase of load carrying capacity to almost a flexural failure.

Jayaprakash et al (2008), conducted tests to study shear capacity of pre-cracked and non- pre-cracked reinforced concrete shear beams with externally bonded bi-directional CFRP strips. The experimental program beams, four control beams, six pre-cracked/repaired beams and six initially strengthened specimens. The rectangular beam had a dimension of $2980 \mathrm{~mm}$ length, $120 \mathrm{~mm}$ width and $310 \mathrm{~mm}$ depth. The variables investigated within this program included longitudinal tensile reinforcement ratio ( $\rho=1.69$ ) for $20 \mathrm{~mm}$ and ( $\rho=1.08$ ) for $16 \mathrm{~mm}$, no steel stirrups, shear span to effective depth ratio (av/d=2.5 and av/d =4), spacing of CFRP strips (80 mm @ 150 mm c/c and 80 mm @ 200 $\mathrm{mm} \mathrm{c} / \mathrm{c}$ ) and orientation of CFRP strips (0/90 deg and $45 / 135 \mathrm{deg}$ ) in 3 sides U- wrap schemes. From the results, they observed that the external CFRP strips act as shear reinforcement similar to the steel stirrups. They also showed that by increasing the amount of longitudinal tensile reinforcement ratio and spacing of CFRP strips, it affected the shear capacity. This study found that the orientation of CFRP strips not only affected the cracking pattern but also affectted the shear capacity.

Godat et al (2010), studied to obtain a clear understanding of size effects for Carbon Fiber-Reinforced Polymer (CFRP) shear-strengthened beams. Their experimental research presented here, investigated the shear performance of rectangular reinforced concrete beams strengthened with CFRP U-strips as well as one completely wrapped with CFRP sheet. Seven rectangular RC beams were grouped into three test series, three control beams, three beams with U-Shaped CFRP jacket and beam with completely wrapped external CFRP sheets. The cross sections were; first series $100 \mathrm{~mm} \times 200 \mathrm{~mm}$ with length $900 \mathrm{~mm}$, second series $200 \times 400 \mathrm{~mm}$ of length $1800 \mathrm{~mm}$ and third series $300 \mathrm{~mm} \times 600 \mathrm{~mm}$ with beam length $2700 \mathrm{~mm}$. All beams were heavily reinforced in bending, no steel stirrups were installed in the right shear span of interest but in the left shear span. It was placed to ensure that the failure would occur in the shear span of interest. From these results, they observed that the larger beam size, CFRP sheet provided less improvement in the shear capacity. They investigated the cracking behaviour of these specimens. Their research presented a Comparison between Test Results and Predictions from Design Guidelines.

Bukhaari et al (2010), studied the shear strengthening of reinforced concrete beams with Carbone Fiber Reinforced Polymer (CFRP) sheet. Seven, two span continuous reinforced concrete (RC) rectangular beams. The cross section of rectangular was $152 \mathrm{~mm} \times 305 \mathrm{~mm}$ and beam length $3400 \mathrm{~mm}$. One beam was un-strengthened (control beam) and, the remaining six were strengthened with different arrangements of CFRP sheet. They studied orientation of fiber (0/90 and 45/135) as main variables. The tests showed that it is beneficial to orientate the fibres in the CFRP sheet at 45 so that they are approximately perpendicular to the shear cracks.

H.K. Lee, S.H. Cheong, S.K. Ha and C.G. Lee (2011), investigated the behaviour and performance of reinforced concrete (RC) T-section deep beams strengthened in shear with CFRP sheets. A total of fourteen reinforced concrete T-section deep beams were designed to be deficient in shear. The cross section of $180 \mathrm{mmx} 460 \mathrm{~mm}$ with flange thickness of $100 \mathrm{~mm}$ and the beam's length of $1800 \mathrm{~mm}$, were used. The specimens were reinforced with longitudinal steel and stirrups near the mid-span. They also studied variables such as; strengthening length, fiber direction combination of CFRP sheets, and an anchorage using U-wrapped CFRP sheets, these variables have significant influence on the shear performance of strengthened deep beams. Their tested Experimental results T-section beams were regarded as deep 
beams, since the shear span-to-effective depth ratio $(\mathrm{a} / \mathrm{d})$ was 1.22 . On the other hand, Crack patterns and behaviour of the tested deep beams were observed during four-point loading tests.

Table 1. Experimental results and numerical simulation of load-carrying capacity of reference RC beams

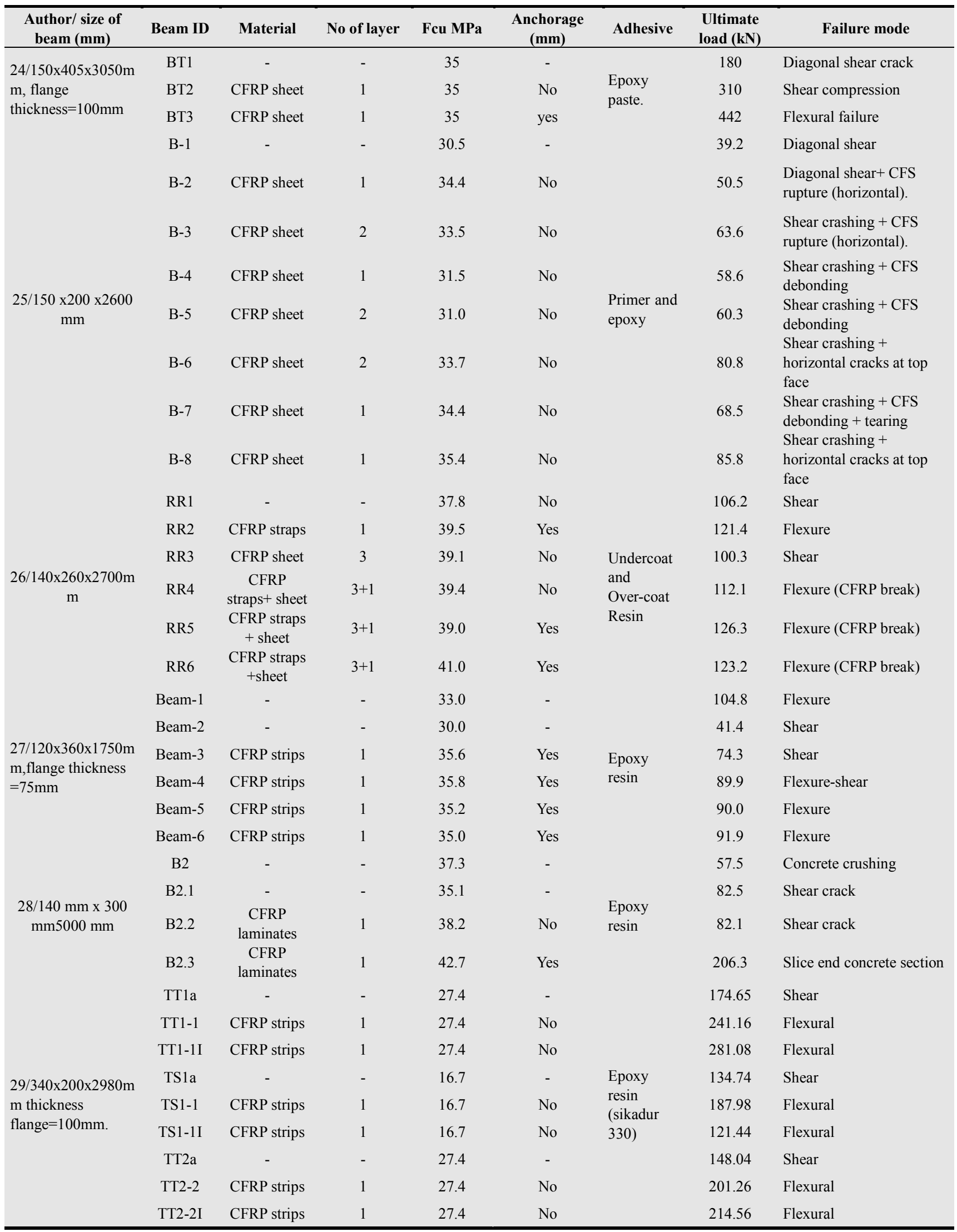




\begin{tabular}{|c|c|c|c|c|c|c|c|c|}
\hline $\begin{array}{c}\text { Author/ size of } \\
\text { beam }(\mathrm{mm})\end{array}$ & Beam ID & Material & No of layer & Fcu MPa & $\begin{array}{c}\text { Anchorage } \\
(\mathrm{mm})\end{array}$ & Adhesive & $\begin{array}{r}\text { Ultimate } \\
\text { load }(k N)\end{array}$ & Failure mode \\
\hline \multirow{19}{*}{$\begin{array}{c}30 / 120 \times 310 \times 2980 \mathrm{~m} \\
\mathrm{~m}\end{array}$} & TS2a & - & - & 16.7 & - & \multirow{18}{*}{$\begin{array}{l}\text { Epoxy } \\
\text { resin } \\
\text { (sikadur } \\
330 \text { ) }\end{array}$} & 108.14 & Flexural \\
\hline & TS2-1 & CFRP strips & 1 & 16.7 & No & & 148.04 & Flexural \\
\hline & TS2-1I & CFRP strips & 1 & 16.7 & No & & 121.44 & Flexural \\
\hline & BT1aa & - & - & 27.38 & No & & 98.14 & Shear \\
\hline & BT1-I & CFRP strips & 1 & 27.38 & No & & 134.73 & Shear-CRP fracture \\
\hline & BT1-1I & CFRP strips & 1 & 27.38 & No & & 174.64 & Shear-CFRP fracture \\
\hline & BT1-2I & CFRP strips & 1 & 27.38 & No & & 134.73 & Shear-CFRP fracture \\
\hline & BS1a & - & - & 27.38 & No & & 74.86 & Shear \\
\hline & BS1-1 & CFRP strips & 1 & 27.38 & No & & 121.42 & Shear-CFRP fracture \\
\hline & BS1-2 & CFRP strips & 1 & 27.38 & No & & 101.46 & Shear-CFRP fracture \\
\hline & BT2a & - & - & 16.73 & No & & 64.88 & Shear \\
\hline & BT2-1 & CFRP strips & 1 & 16.73 & No & & 134.73 & Shear-CFRP fracture \\
\hline & BT2-2 & CFRP strips & 1 & 16.73 & No & & 121.42 & Shear-CFRP fracture \\
\hline & BT2-2I & CFRP strips & 1 & 16.73 & No & & 154.68 & Shear-CFRP fracture \\
\hline & BS2a & - & - & 16.73 & No & & 61.56 & Flexural \\
\hline & BS2-1 & CFRP strips & 1 & 16.73 & No & & 108.19 & Flexural \\
\hline & BS2-2 & CFRP strips & 1 & 16.73 & No & & 81.51 & Flexural \\
\hline & BS2-2I & CFRP strips & 1 & 16.73 & No & & 88.16 & Flexural \\
\hline & BS2-1I & CFRP strips & 1 & 16.73 & No & \multirow{9}{*}{$\begin{array}{l}\text { Epoxy } \\
\text { resin }\end{array}$} & 68.21 & Flexural \\
\hline \multirow{8}{*}{$\begin{array}{l}31 / \mathrm{a}) 100 \times 200 \times 900 \\
\mathrm{~mm} \\
\text { b) } 200 \times 400 \times 1800 \mathrm{~m} \\
\mathrm{~m} \\
\mathrm{c}) \\
300 \times 600 \times 2700 \mathrm{~mm}\end{array}$} & $\mathrm{RC} 1$ & - & - & 51.2 & No & & 160 & Concrete crushing \\
\hline & $\mathrm{U} 4$ & CFRP jacket & 1 & 51.2 & No & & 203 & Debonding \\
\hline & $\mathrm{RC} 2$ & - & - & 49.7 & No & & 709 & Concrete crushing \\
\hline & U5 & CFRP jacket & 1 & 51.2 & No & & 809 & Debonding \\
\hline & $\mathrm{RC} 3$ & - & - & 50.5 & No & & 1626 & Concrete crushing \\
\hline & U6 & CFRP jacket & 1 & 51.0 & No & & 2018 & Debonding \\
\hline & W7 & CFRP sheet & 1 & 50.7 & No & & 2221 & CFRP rupture \\
\hline & $\mathrm{C} 1$ & - & - & 60 & - & & 250 & Shear \\
\hline \multirow{5}{*}{$\begin{array}{c}32 / 152 \times 305 \times 3400 \mathrm{~m} \\
\mathrm{~m}\end{array}$} & $\mathrm{C} 2$ & CFRP sheet & 1 & 60 & No & \multirow{5}{*}{ Epoxy } & 384.7 & Sheet delamination \\
\hline & $\mathrm{C} 3$ & CFRP sheet & 1 & 60 & No & & 423.2 & Sheet delamination \\
\hline & $\mathrm{C} 4$ & CFRP sheet & 1 & 60 & No & & 383.2 & Sheet delamination \\
\hline & $\mathrm{C} 5$ & CFRP sheet & 1 & 60 & No & & 452.0 & Sheet rupture \\
\hline & $\mathrm{C} 6$ & CFRP sheet & 1 & 60 & No & & 480.9 & Sheet delamination \\
\hline \multirow{11}{*}{$\begin{array}{l}33 / 180 \times 460 \times 1800 \mathrm{~m} \\
\mathrm{~m}, \text { flange thickness } \\
=100 \mathrm{~mm} .\end{array}$} & D6 & CFRP sheet & 1 & 44 & No & \multirow{11}{*}{$\begin{array}{l}\text { primer and } \\
\text { saturant } \\
\text { resin }\end{array}$} & 461.7 & \multirow{11}{*}{$\begin{array}{l}\text { Sheet delamination } \\
\text { shear-compression } \\
\text { shear-compression due to } \\
\text { partial delamination } \\
\text { shear-compression due to } \\
\text { partial delamination } \\
\text { shear-compression due to } \\
\text { partial delamination } \\
\text { shear-compression due to } \\
\text { partial delamination } \\
\text { shear-compression due to } \\
\text { partial delamination } \\
\text { shear-compression due to } \\
\text { partial delamination } \\
\text { shear-compression due to } \\
\text { partial delamination } \\
\text { shear-compression due to } \\
\text { partial delamination } \\
\text { shear-compression due to } \\
\text { rupture of CFRP sheets }\end{array}$} \\
\hline & CT & - & - & 22.45 & - & & 458.2 & \\
\hline & $\begin{array}{c}\text { CS-QL-H } \\
\text { P }\end{array}$ & CFRP sheet & 1 & 22.45 & No & & 528.6 & \\
\hline & $\begin{array}{c}\text { CS-QL-V } \\
\text { P }\end{array}$ & CFRP sheet & 1 & 22.45 & No & & 505.9 & \\
\hline & $\begin{array}{c}\text { CS-QL-C } \\
\text { P }\end{array}$ & CFRP sheet & 1 & 22.45 & No & & 512.9 & \\
\hline & $\begin{array}{c}\text { CS-QL-A } \\
\text { P }\end{array}$ & CFRP sheet & 1 & 22.45 & No & & 525.3 & \\
\hline & $\begin{array}{c}\text { CS-HL-H } \\
\text { P }\end{array}$ & CFRP sheet & 1 & 22.45 & No & & 599.4 & \\
\hline & $\begin{array}{c}\text { CS-HL-V } \\
\text { P }\end{array}$ & CFRP sheet & 1 & 22.45 & No & & 528.6 & \\
\hline & $\begin{array}{c}\text { CS-HL-C } \\
\text { P }\end{array}$ & CFRP sheet & 1 & 22.45 & No & & 562.7 & \\
\hline & $\begin{array}{c}\text { CS-HL-A } \\
\text { P }\end{array}$ & CFRP sheet & 1 & 22.45 & No & & 547.2 & \\
\hline & CS-FL-HP & CFRP sheet & 1 & 22.45 & No & & 760.5 & \\
\hline
\end{tabular}




\begin{tabular}{|c|c|c|c|c|c|c|c|c|}
\hline $\begin{array}{c}\text { Author/ size of } \\
\text { beam (mm) }\end{array}$ & Beam ID & Material & No of layer & Fcu MPa & $\begin{array}{c}\text { Anchorage } \\
(\mathrm{mm})\end{array}$ & Adhesive & $\begin{array}{l}\text { Ultimate } \\
\text { load (kN) }\end{array}$ & Failure mode \\
\hline & CS-FL-VP & CFRP sheet & 1 & 22.45 & No & & 542.1 & \multirow{4}{*}{$\begin{array}{l}\text { shear-compression due to } \\
\text { partial delamination } \\
\text { shear-compression due to } \\
\text { partial delamination } \\
\text { shear-compression due to } \\
\text { partial delamination } \\
\text { shear-compression due to } \\
\text { partial delamination }\end{array}$} \\
\hline & CS-FL-CP & CFRP sheet & 1 & 22.45 & No & & 660.5 & \\
\hline & CS-FL-AP & CFRP sheet & 1 & 22.45 & No & & 646.5 & \\
\hline & CS-FL-CP & CFRP sheet & 1 & 22.45 & Yes & & 699.5 & \\
\hline
\end{tabular}

\section{Comments on the Actual State of Art}

From the above review of literature (Table-1), illustrates that although substantial research has been conducted on CFRP strengthening of reinforced concrete beams still, the behaviour of CFRP strengthened beams in shear was young as compared with strengthened beams in flexural. There is no design guideline for optimizing and choosing the thickness of CFRP sheet/laminate for strengthening RC beams. From the researches conducted on RC rectangular and T-Beams sections which, were strengthened in shear with CFRP and which were strengthened with 1, 2 and 3 layers of CFRP laminate.

\section{Conclusions}

This paper reviewed the existing research works on reinforced concrete beams strengthened by CFRP. The beam strengthened with more than one layer of CFRP laminate unnecessarily increased the strengthening time as well as cost by providing more than one layer of CFRP laminate.

The importance of the study in the strengthening of the beam using CFRP laminate in the strengthening system provides an economical and versatile solution for extending the service life of reinforced concrete structures. From the literature, it is evident that epoxy resin is favoured in strengthening and also the end of anchorage was used to eliminate the debonding failure. Future research is needed for a complete awareness for strengthening reinforced concrete beams with FRP, with the aim to efficiently contribute in the concrete structures repair tasks as well as, to decrease the dimensional stability of the structure. A working knowledge of how material properties change as a function of climate, time and loading will also be of great value to the engineering and design communities. Moreover, FRP in concrete allows engineers to increase or decrease margins of safety depending on environmental and stress conditions, generic FRP type and required design life.

\section{Acknowledgment}

The authors gratefully acknowledge the financial support from Fundamental Research Grant Scheme (FRGS) funded by the Ministry of Higher Education, Malaysia.

\section{References}

[1] Gyuseon Kim, Jongsung Sim and Hongseob Oh (2008) Shear strength of strengthened RC beams with FRPs in shear. Construction and Building Materials, pp. 1261-1270.

[2] Oral Buyukozturk, Oguz Gunes and Erdem Karaca (2004). Progress on understanding deboning problems in reinforced concrete and steel members strengthened using FRP composites. Construction and Building Materials, pp. 9-19.

[3] Shit, T.2011. Experimental and Numerical Study on Behavior of Externally Bonded RC T-Beams Using GFRP Composites. Department of Civil Engineering National Institute of Technology Rourkela, Orissa: : Master's Thesis.

[4] Bousselham, A., and Chaallal, O., (2004),“ Shear Strengthening Reinforced Concrete Beams with Fiber-Reinforced Polymer: Assessment of Influencing Parameters and Required Research, ACI Structural Journal, V. 101, No. 2, Mar.-Apr., pp. 219-227

[5] Matthys, S., and Triantafillou, T., (2001), "Shear and Torsion Strengthening with Externally Bonded FRP Reinforcement," Proceedings of the International Workshop on Composites in Construction: A Reality, E. Cosensa, G. Manfredi, and A. Nanni, eds., Capri, Italy, pp. 203- 210.

[6] Tan, K.Y. 2003. Evaluation of Externally Bonded CFRP System for the Strengthening of RC Slabs. University of Missouri-Rolla. Center for Infrastructure Engineering Studies: Master's Thesis.

[7] Ekenel,M ., Stephen,V., Myers, J.J. \& Zoughi,R.(2004). Microwave NDE of RC Beams Strengthened with CFRP Laminates Containing Surface Defects and Tested Under Cyclic Loading. Electrical and Computer Engineering, University of Missouri-Rolla, Rolla, MO 65409, USA, pp $1-8$.

[8] Aram MR, Czaderski C, Motavalli M (2008). Debonding failure modes of flexural FRP-strengthened RC beams. Composites Part B: Engineering. 39: 826-41

[9] Pham H, Al-Mahaidi R (2004). Assessment of available prediction models for the strength of FRP retrofitted RC beams. Composite Structures. 66: 601-10

[10] Teng GJ, Smith TS, Yao J, Chen JF (2003). Intermediate crack-induced debonding in RC beams and slabs. Construction and Building Materials. 17: 447-62

[11] Smith S.T and Teng J.G. 2002. FRP-strengthened RC beams I: Review of Debonding Strength. Eng Struct. 24: 385-95. 
[12] Smith S.T and Teng J.G. 2002. FRP-strengthened RC beams II: Assessment of Debonding Strength Models. Engineering Structures. 24: 397-417.

[13] Manuel A.G. Silva and Hugo Biscaia. 2008. Degradation of Bond between FRP and RC Beams. Composite Structures. 85: $164-174$

[14] Ceroni F (2010). Experimental performances of RC beams strengthened with FRP materials. Construction and Building Materials. 24: 1547-59.

[15] Jumaat MZ, Alam MA (2010). Experimental and numerical analysis of end anchored steel plate and CFRP laminate flexurally strengthened r. c. beams. Int. J. Phys. Sci. $5: 132-144$

[16] Wang YC, Hsu K (2009). Design recommendations for the strengthening of reinforced concrete beams with externally bonded composite plates. Composite Structures. 88: 323-32.

[17] Alam MA, Jumaat MZ (2008). Behavior of U and L shaped end anchored steel plate strengthened reinforced concrete beams. European Journal of Scientific Research. 22: 184-96.

[18] Ceroni F, Pecce M, Matthys S, Taerwe L (2008). Debonding strength and anchorage devices for reinforced concrete elements strengthened with FRP sheets. Composites Part B: Engineering. 39: 429-41.

[19] Xiong GJ, Jiang X, Liu JW, Chen L (2007). A way for preventing tension delamination of concrete cover in midspan of FRP strengthened beams. Construction and Building Materials. 21: 402-8.

[20] Pham H, Al-Mahaidi R (2006). Prediction models for debonding failure loads of carbon fiber reinforced polymer retrofitted reinforced concrete beams. J Compos Constr, ASCE. 10: 48-59.

[21] Costa IG, Barros JAO (2010). Flexural and shear strengthening of RC beams with composite materials the influence of cutting steel stirrups to install CFRP strips. Cement and Concrete Composites. In Press, Corrected Proof.

[22] Ombres ,L (2010). Prediction of intermediate crack debonding failure in FRP-strengthened reinforced concrete beams. Composite Structures. 92: 322-9.

[23] Mohamed,B.B, Abdelouahed T, Samir B (2009). Approximate analysis of adhesive stresses in the adhesive layer of plated RC beams. Computational Materials Science. 46: 15-20.
[24] Khalifa, A., Alkhrdaji, T., Nanni, A. \& Lansburg, S. (1999). Anchorage of Surface Mounted FRP Reinforcemen.Concrete International: Design and Construction, Vol. 21, No.10, pp. 49-5.

[25] Adhikary, B.B.,ASCE,M. \&Musuyoshi, H. (2004). Behavior of Concrete Beams Strengthened in Shear with Carbon-Fiber Sheets. Journal of Composites for Construction Vol. 8, No.3, pp. 258-264.

[26] Al-Amery, R. \& Al-Mahaidi, R. (2006). Coupled Flexural-Shear Retrofitting of RC Beams using CFRP straps. $13^{\text {th }}$ Intenational Conference of Composite Structures, Melbourne, Australia. . Composite Structures 75, pp. 457-464.

[27] Anil, Ö (2006). Improving shear capacity of RC T-beams using CFRP composites subjected to cyclic load. Cement \& Concrete Composites 28, pp. 638-649

[28] Bencardino, F.,Spadea,G.\& Swamy,R.N (2007). The Problem of Shear in RC Beams Strengthened with CFRP laminates. Composite Structures 21, pp. 1997-2006.

[29] J. Jayaprakash, A.A. Abdul Samad, A.A. Ashrabov and K.K. Chong (2008). Experimental Investigation on Shear Resistance Behaviour of RC Precracked and Non-Precracked T-Beams using Discrete CFRP Strips. International Journal of Integrated Engineering (Issue on Civil and Environmental Engineering) pp.1-15

[30] J. Jayaprakash, A.A. Abdul Samad, A.A. Ashrabov Abbasovich \& Abang Ali (2008). Shear Capacity of Percracked and Non- Percracked Reinforced Concrete Shear Beams with Externally bonded Bi-directional CFRP strips. \& Concrete Composites 22, pp. 1148-1165.

[31] Godat, A.,Qu, Z. Lu, Z.X.,Labossiere, P., Ye, P.L., Neale, WK \& ASCE, M.(2010). Size Effects for Reinforced Concrete Beams Strengthened in Shear with CFRP Strips. Journal of composites for construction, pp. 260-271.

[32] Bukhari, A.I.,Vollum, L.R., Ahmad, S.\& Sagaseta, J (2010). Shear Strengthening of Reinforced Concrete beams with CFRP. Magazine of Concrete Research, 62, No. 1, pp.65-77.

[33] H.K. Lee, S.H. Cheong, S.K. Ha and C.G. Lee (2011), Behavior and performance of RC T-section deep beams externally strengthened in shear with CFRP sheets. Composite Structures, pp. 911-922 